\title{
Analisis Dampak Situasi Pandemi Covid-19 terhadap Kesejahteraan Pedagang Pasar Tradisional Larangan di Sidoarjo
}

\author{
*Ilham Putra Sahbana, Juliani Pudjowati, Susi Tri Wahyuni \\ Fakultas Ekonomi dan Bisnis Universitas Bhayangkara Surabaya, Indonesia
}

DOI: $10.46821 /$ bharanomics.v2i1.186

\begin{abstract}
Abstrak
Penelitian ini bertujuan untuk mengetahui analisis dampak situasi pandemi covid-19 terhadap kesejahteraan pedagang Pasar Tradisional Larangan di Sidoarjo. Informan dari penelitian ini 6 orang yang terdiri dari pedagang sayuran, penjual sandal/sepatu, penjual alat elektronik, penjual pisang, pedagang ayam, dan penjual sosis. Teknik pengumpulan data yang digunakan dalam penelitian ini adalah teknik triangulasi (observasi, wawancara dan dokumentasi). Metode penelitian ini menggunakan metode penelitian deskriptif melalui metode kualitatif. Hasil penelitian ini adalah bahwa dimasa pandemi covid-19 sekarang ini sangat berpengaruh terhadap kesejahteraan pedagang pasar seperti menurunnya penghasilan para pedagang dan banyak dagangan yang belum habis terjual. Hal tersebut untuk mengatasi menurunnya penghasilan, para pedagang berinisiatif mengolah dagangannya yang belom terjual habis untuk dijual kembali di rumah demi mencukupi kebutuhan sehari - harinya pada situasi pandemi covid-19 saat ini.
\end{abstract}

Kata kunci: Pandemi covid-19, Kesejahteraan pedagang pasar, Pasar Tradisional

\begin{abstract}
:
This study aims to determine the analysis of the impact of the COVID-19 pandemic situation on the welfare of traders at the Larangan Traditional Market in Sidoarjo. The informants of this study were 6 people consisting of vegetable traders, sandal/shoes sellers, electronic equipment sellers, banana sellers, chicken traders, and sausage sellers. Data collection technique used in this research is triangulation technique (observation, interview and documentation). This research method uses descriptive research methods through qualitative methods.The results of this study are that during the current covid-19 pandemic, it is very influential on the welfare of market traders, such as a decrease in the income of traders and a lot of merchandise that has not been sold out. This is to overcome the decline in income, traders take the initiative to process their wares that have not been sold out to be resold at home to meet their daily needs in the current COVID-19 pandemic situation.
\end{abstract}

Keywords: Covid-19 Pandemic, Welfare of market traders, Traditional Markets

\section{PENDAHULUAN}

Manusia telah mengenal dan melakukan kegiatan jual beli sebagai bentuk pemenuhan kebutuhan. Dalam kegiatan jual beli, keberadaan pasar merupakan salah satu hal yang paling penting untuk melakukan kegiatan tersebut. Bangsa Indonesia telah lama mengenal pasar khususnya pasar tradisional.

Pasar tradisional adalah sebuah tempat yang terbuka dimana terjadi proses transaksi jual beli yang dimungkinkan proses tawar-menawar. Di pasar tradisional pengunjung tidak selalu menjadi pembeli, namun pengunjung bisa menjadi penjual, bahkan setiap orang bisa menjual dagangannya di pasar tradisional. Pasar 


\section{Bharanomics}

Vol. 2 No. 12021

tradisional merupakan sektor perekonomian yang sangat penting bagi mayoritas penduduk di Indonesia. Masyarakat miskin yang bergantung kehidupannya pada pasar tradisional tidak sedikit, menjadi pedagang di pasar tradisional merupakan alternatif pekerjaan di tengah banyaknya pengangguran di Indonesia (Masitoh, 2013).Salah satu contoh pasar tradisional adalah Pasar Tradisional Larangan. Pasar Tradisional Larangan merupakan pasar tradisional terbesar di Sidoarjo, yang tepatnya berada di Desa Larangan Kecamatan Candi Kabupaten Sidoarjo. Awalnya daerah tersebut masih berupa persawahan yang sedikit sekali penduduknya dan masih sepi.

Berdagang di Pasar Larangan merupakan sebuah usaha dalam meningkatkan perekonomian masyarakat. Dengan adanya usaha yang demikian diharapkan untuk memungkinkan masyarakat dalam menciptakan kondisi ekonomi yang lebih baik dari sebelumnya. Dengan itu dimana pendidikan sangatlah penting untuk memajukan usahanya. Pendidikan adalah kegiatan yang dilakukan manusia secarasadar dan terprogram guna membangunpersonalitas yang baikdan mengembangkan kemampuan atau bakatyang ada pada diriindividu manusia agar mencapai tujuan atau target tertentu dalam menjalani hidup.Berdasarkan uraian diatas dapat disimpulkan bahwa pendidikan adalah usaha menyiapkan dan membekali generasi muda ilmu pengetahuan, pengalaman dan kemampuan dalam memecahkan masalah yang prosesnya berlangsung sejak lahir hingga akhir hayat, baikjasmani maupun rohani (Trahati, 2015).

Dengan adanya pendidikan yang tinggi diperolehnya pendapatan atau penghasilan dalam usahanya tersebut, Penghasilan (income) adalah kenaikan manfaat ekonomi selama periode pelaporan dalam bentuk arus masuk atau peningkatan aset, atau penurunan kewajiban yang mengakibatkan kenaikan ekuitas yang tidak berasal dari kontribusi penanam modal. Penghasilan meliputi pendapatan (revenue) dan keuntungan (gain). Pendapatan adalah penghasilan yang timbul dalam pelaksanaan aktivitas entitas yang biasa dan dikenal dengan sebutan yang berbeda seperti penjualan, imbalan, bunga, dividen, royalti dan sewa (Sodikin dan Riyono, 2014).

Sedikit membahas tentang Covid-19, Covid-19 atau Corona Virus adalah keluarga besar virus dari Subfamili Orthocronavirinae dalam keluarga Coronaviridae dan Ordo Nidovirales (Yunus dan Rezki, 2020), yang menyebabkan penyakit pada manusia dan hewan. Pada manusia biasanya menyebabkan penyakit infeksi saluran pernapasan, mulai flu biasanya hingga penyakit yang serius seperti Middle East Respiratory Syndrome (MERS) dan sindrom pernapasan akut berat/Severe Acute Respiratory Syndrome (SARS). Corona Virus jenis baru yang ditemukan pada manusia sejak kejadian luar biasa muncul di Wuhan Cina, pada Desember 2019, kemudian diberi nama Severe Acute Respiratory Syndrome Coronavirus 2 (SARS-COV2), dan menyebabkan penyakit Coronavirus Disease-2019 (COVID-19).

Sebagai wujud kebijakan pemerintah menghadapi pandemi Covid-19, masyarakat dihimbau untuk mengurangi aktivitas di luar rumah. Tentunya kondisi ini sangat berpengaruh pada ekonomi para pedagang. Ekonomi merupakan faktor penting di kehidupan manusia. Kehidupan keseharian manusia dapat dipastikan selalu bersinggungan dengan kebutuhan ekonomi (Honoatubun, 2020). Pembatasan aktivitas akibat pandemi Covid-19 telah menimbulkan kerugian ekonomi secara nasional (Hadiwardoyo, 2020). 
Kesejahteraan merupakan sejumlah kepuasan yang diperoleh seseorang dari hasil mengkonsumsi pendapatan yang diterima, namun tingkatan dari kesejahteraan itu sendiri merupakan sesuatu yang bersifat relatif karena tergantung dari besarnya kepuasan yang diperoleh dari hasil mengkonsumsi pendapatan tersebut. Keterkaitan antara konsep kesejahteraan dan konsep kebutuhan adalah dengan terpenuhinya kebutuhan - kebutuhan tersebut, maka seseorang sudah dinilai sejahtera, karena tingkat kebutuhan tersebut secara tidak langsung sejalan dengan indikator kesejahteraan (Pratama, dkk 2012).

Berdasarkan latar belakang yang telah diuraikan di atas maka dapat dirumuskan masalah sebagai berikut : 1) Bagaimana kenaikan pendapatan pedagang pasar terhadap kesejahteraannya setelah terkena dampak pandemi covid-19 di Sidoarjo?, 2) Bagaimana tingkat pendidikan pedagang pasar dalam memajukan usaha terhadap kesejahteraannya selama adanya wabah pandemi covid-19 di Sidoarjo?, 3) Bagaimana pembatasan sosial (social distancing) terhadap kesejahteraan pedagang pasar selama adanya wabah pandemi covid-19 di Sidoarjo?, 4) Bagaimana peran pemerintah terhadap kesejahteraan pedagang pasar setelah terkena dampak pandemi covid-19 di Sidoarjo?

Sedangkan tujuan penelitian adalah 1) Untuk membuktikan dan menganalisa bagaimana kenaikan pendapatan pedagang pasar terhadap kesejahteraannya setelah terkena dampak pandemi covid-19 di Sidoarjo, 2) Untuk membuktikan dan menganalisa bagaimana tingkat pendidikan pedagang pasar dalam memajukan usaha terhadap kesejahteraannya selama adanya wabah pandemi covid-19 di Sidoarjo, 3) Untuk membuktikan dan menganalisa bagaimana pembatasan sosial (social distancing) terhadap kesejahteraan pedagang pasar selama adanya wabah pandemi covid-19 di Sidoarjo, 4) Untuk membuktikan dan menganalisa bagaimana peran pemerintah terhadap kesejahteraan pedagang pasar setelah terkena dampak pandemi covid-19 di Sidoarjo.

\section{TINJAUAN PUSTAKA}

\section{Teori Pasar Tradisional}

Pasar tradisional adalah sebuah tempat yang terbuka dimana terjadi proses transaksi jual beli yang dimungkinkan proses tawar-menawar. Di pasar tradisional pengunjung tidak selalu menjadi pembeli, namun pengunjung bisa menjadi penjual, bahkan setiap orang bisa menjual dagangannya di pasar tradisional. Pasar tradisional merupakan sektor perekonomian yang sangat penting bagi mayoritas penduduk di Indonesia. Masyarakat miskin yang bergantung kehidupannya pada pasar tradisional tidak sedikit, menjadi pedagang di pasar tradisional merupakan alternatif pekerjaan di tengah banyaknya pengangguran di Indonesia (Masitoh, 2013).

\section{Teori Pendidikan}

Pendidikan adalah kegiatan yang dilakukan manusia secara sadar dan terprogram guna membangun personalitas yang baik dan mengembangkan kemampuan atau bakat yang ada pada diri individu manusia agar mencapai tujuan atau target tertentu dalam menjalani hidup. Berdasarkan uraian diatas dapat disimpulkan bahwa pendidikan adalah usaha menyiapkan dan membekali generasi muda ilmu pengetahuan, pengalaman dan kemampuan dalam memecahkan masalah yang prosesnya berlangsung sejak lahir hingga akhir hayat, baik jasmani maupun rohani (Trahati, 2015). 


\section{Teori Pendapatan}

Pendapatan merupakan sumber penghasilan seseorang untuk memenuhi kebutuhan sehari-hari dan sangat penting artinya bagi kelangsungan hidup dan penghidupan seseorang secara langsung maupun tidak langsung (Suroto, 2014).

\section{Teori Corona Virus (Covid-19)}

Corona Virus (Covid-19) adalah keluarga besar virus dari Subfamili Orthocronavirinae dalam keluarga Coronaviridae dan Ordo Nidovirales (Yunus dan Rezki, 2020), yang menyebabkan penyakit pada manusia dan hewan. Pada manusia biasanya menyebabkan penyakit infeksi saluran pernapasan, mulai flu biasanya hingga penyakit yang serius seperti Middle East Respiratory Syndrome (MERS) dan sindrom pernapasan akut berat/Severe Acute Respiratory Syndrome (SARS). Corona Virus jenis baru yang ditemukan pada manusia sejak kejadian luar biasa muncul di Wuhan Cina, pada Desember 2019, kemudian diberi nama Severe Acute Respiratory Syndrome Coronavirus 2 (SARS-COV2), dan menyebabkan penyakit Coronavirus Disease-2019 (COVID-19). Covid-19 merupakan penyakit menular yang disebabkan oleh coronavirus (Abdussomad, 2020).

\section{Teori Kesejahteraan}

Kesejahteraan merupakan sejumlah kepuasan yang yang diperoleh seseorang dari hasil mengkonsumsi pendapatan yang diterima, namun tingkatan dari kesejahteraan itu sendiri merupakan sesuatu yang bersifat relatif karena tergantung dari besarnya kepuasan yang diperoleh dari hasil mengkonsumsi pendapatan tersebut. Keterkaitan antara konsep kesejahteraan dan konsep kebutuhan adalah dengan terpenuhinya kebutuhan-kebutuhan tersebut, maka seseorang sudah dinilai sejahtera, karena tingkat kebutuhan tersebut secara tidak langsung sejalan dengan indikator kesejahteraan (Pratama, dkk 2012).

\section{Kerangka Konseptual}

Dengan melihat kondisi sekarang ini yang terdampak Pandemi Covid-19 sangat berpengaruh terhadap perekonomian Pasar Tradisional Larangan Sidoarjo terutama pada pemenuhan kebutuhan dan pedagang pasarnya. Berpengaruhnya pemenuhan kebutuhan dan pedagang pasar menyebabkan pengaruh juga pada tingkat kesejahteraan. Dari semua permasalahan diatas dapat di tulis judul Analisis Dampak Situasi Pandemi Covid-19 Terhadap Kesejahteraan Pedagang Pasar Tradisional Larangan di Sidoarjo (Gambar 1). 


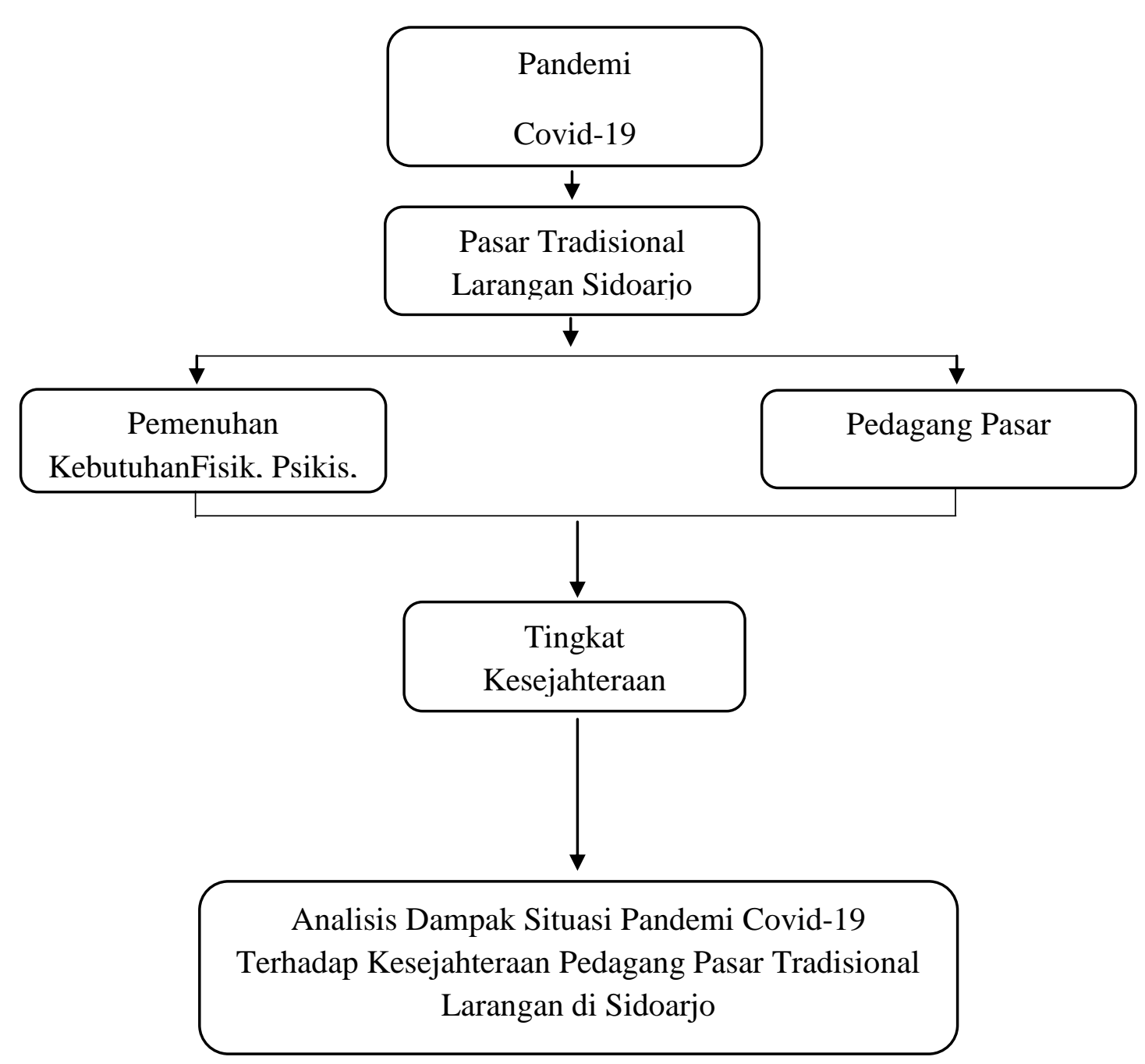

\section{Gambar 1. Kerangka Konseptual}

Sumber : Peneliti (2021)

\section{METODE PENELITIAN}

Pada penelitian ini pendekatan yang digunakan oleh peneliti adalah metode pendekatan kualitatif. Sedangkan sumber data yang digunakan dalam penelitian ini adalah data primer dan data sekunder. Teknik pengumpulan data yang digunakan adalah Observasi, Wawancara, dan Dokumentasi. Teknik pengujian data yang digunakan pada penelitian ini digunakan uji kredibilitas untuk menguji keabsahan data. Uji kredibilitas data dilakukan dengan triangulasi. Pada penelitian ini, peneliti menggunakan triangulasi sumber. Triangulasi sumber adalah menguji kredibilitas data yang dilakukan dengan cara mengecek data yang telah diperoleh melalui beberapa sumber. Pengujian data dalam penelitian ini dilakukan dengan cara wawancara, observasi, dan dokumentasi, sehingga data yang terkumpul diperoleh lebih dari satu informan, hal tersebut tentunya akan menghasilkan berbagai pendapat pula. Oleh karena itu penelitian ini menggunakan triangulasi supaya diperoleh data yang valid yang dapat dipertanggungjawabkan nantinya. Maka dari itu triangulasi yang digunakan dalam penelitian ini adalah triangulasi sumber. Dalam hal ini data yang diperoleh 
Bharanomics

Vol. 2 No. 12021

Ilham Putra Sahbana dkk., Analisis Dampak Situasi Covid-19

akan dibandingkan dicek informasi yang telah diperoleh dari wawancara mendalam terhadap informan satu dengan infroman lainnya. Informan dalam penelitian ini adalah dari para pedagang Pasar Tradisional Larangan Sidoarjo.

\section{HASIL DAN PEMBAHASAN}

\section{Kenaikan Pendapatan Pedagang Pasar Terhadap Kesejahteraannya Setelah Terkena Dampak Pandemi Covid-19 di Sidoarjo}

Pendapatan dikatakan sebagai jumlah penghasilan yang diperoleh dari hasil pekerjaan dan biasanya pendapatan seseorang dihitung setiap tahun atau setiap bulan (Samuelson dan Nordhaus, 2013). Dari paparan diatas, peneliti mendapatkan beberapa data dari hasil observasi dan wawancara yang dilakukan di Pasar Tradisional Larangan Sidoarjo. Berdasarkan dari hasil wawancara dengan pihak-pihak terkait, dapat dijelaskan bahwa, 'Bagaimana Kenaikan Pendapatan Pedagang Pasar Terhadap Kesejahteraannya Setelah Terkena Dampak Pandemi Covid-19 di Sidoarjo?'”. Hasilnya sangat berpengaruh, dikarenakan pada situasi pandemi covid-19 sekarang ini pendapatan pedagang pasar jadi menurun drastis dibandingkan dari tahun kemarin pendapatan jauh lebih meningkat. Penurunan pendapatan ini juga sangat berpengaruh pada kelangsungan hidup pedagang. Pedagang yang kehabisan modal tidak dapat melanjutkan usahanya dan akhirnya bisa gulung tikar.

\section{Tingkat Pendidikan Pedagang Pasar Dalam Memajukan Usaha Terhadap Kesejahteraannya Selama Adanya Wabah Pandemi Covid-19 di Sidoarjo}

Pendidikan merupakan salah satu indikator utama pembangunan dan kualitas sumber daya manusia, sehingga kualitas sumber daya manusia sangat tergantung dari kualitas pendidikan. Pendidikan merupakan bidang yang sangat penting dan strategis dalam pembangunan nasional, karena merupakan salah satu penentu kemajuan suatu bangsa. Pendidikan bahkan merupakan sarana paling efektif untuk meningkatkan kualitas hidup dan derajat kesejahteraan masyarakat, serta yang dapat mengantarkan bangsa mencapai kemakmuran.

Para pedagang yang pernah mengenyam pendidikan tentunya jauh lebih mempunyai ketrampilan yang lebih daripada para pedagang yang tidak pernah mengenyam pendidikan, mereka hanya bisa pasrah dengan kondisi yang ada sekarang. Para pedagang yang berpendidikan, lebih mempunyai inisiatif apabila ada dagangan dari mereka ada yang belum laku terjual. Contohnya saja seperti Pak Herman (Penjual sayuran), beliau mempunyai inisiatif untuk mengolah sayuran yang tidak laku terjual dengan cara mengolahnya kembali menjadi makanan ringan seperti lumpia basah atau lumpia kering. Dengan begitu Pak Herman dapat memperoleh sedikit pendapatan tambahan. Bu Indah (Penjual pisang), Beliau mengolah dagangan yang tidak laku terjual menjadi pisang keju. Pak Sapto (Penjual ayam potong), Beliau mengolah dagangan yang tidak laku terjual menjadi ayam geprek. Bu Surti (Penjual sosis), Beliau mengolah dagangan yang tidak laku terjual menjadi sosis bakar atau sosis goreng. Dan dari penjualannya tersebut penghasilannya juga lumayan bisa menambah pendapatan. Pak Syaiful (Penjual sandal dan sepatu), Beliau lebih menjual model - model sepatu yang sesuai musim seperti musim olahraga. Untuk menambah pendapatannya Pak Syaiful menjual barang dagangannya secara online. Berbeda dengan Bu Anita (Penjual alat elektronik) hanya lulusan SD yang hanya bisa pasrah dengan keadaan, hanya menunggu pembeli datang. Dari pernyataan diatas dapat disimpulkan bahwa 
pedagang yang berpendidikan, lebih mempunyai inisiatif untuk memajukan usahanya.

\section{Pembatasan Sosial (Social Distancing) terhadap Kesejahteraan Pedagang Pasar Selama Adanya Wabah Pandemi Covid-19 di Sidoarjo}

Pembatasan sosial (social distancing) adalah pembatasan kegiatan tertentu penduduk dalam suatu wilayah yang diduga terinfeksi penyakit dan/atau terkontaminasi sedemikian rupa untuk mencegah kemungkinan penyebaran penyakit atau kontaminasi. Mengacu kepada aturan tersebut social distancing bertujuan menekan potensi penyebaran penyakit menular, dimana social distancing bertujuan untuk membatasi kegiatan sosial orang untuk menjauh dari kontak fisik dan keramaian. Dalam penerapan social distancing, seseorang tidak diperkenankan untuk berjabat tangan serta senantiasa memperhatikan dan menjaga jarak setidaknya 1- 2 meter saat berinteraksi dengan orang lain, terutama dengan seseorang yang sedang sakit atau beresiko tinggi menderita Covid-19, serta tidak meninggalkan rumah kecuali untuk kondisi yang sangat gening (Setiawan, 2020).

Semenjak diterapkannya pembatasan sosial (social distancing) penghasilan Pedagang Pasar Tradisional Larangan Sidoarjo mengalami penurunan. Hal ini disebabkan karena para pembeli takut untuk berbelanja ke pasar dan berkerumun. Karena sepinya pembeli membuat pedagang banyak mengalami kerugian.

\section{Peran Pemerintah terhadap Kesejahteraan Pedagang Pasar setelah terkena Dampak Pandemi Covid-19}

Covid-19 merupakan penyakit menular yang disebabkan oleh coronavirus. Dampak yang ditimbulkan akibat adanya wabah covid-19 ternyata tidak hanya menyerang buruh-buruh pabrik saja yang dirumahkan atau para pengemudi ojek online yang kehilangan banyak penumpang, melainkan berdampak pula pada para pedagang buah, sayur, daging, dan bahan pokok lainnya yang kesehariannya berjualan di pasar. Pemerintah menganjurkan khususnya untuk pedagang pasar supaya mematuhi protokol kesehatan, selain itu juga pemerintah memberlakukan pembatasan sosial (social distancing) dimana bertujuan untuk membatasi kegiatan atau kontak fisik dan keramaian.

Peraturan Bupati Sidoarjo Nomor 31 Tahun 2020 tentang 'Pedoman Pelaksanaan Pembatasan Sosial Berskala Besar Dalam Penanganan Wabah Corona Virus Disease 2019“' mengungkapkan :

1. Bahwa sehubungan dengan semakin meluasnya penyebaran Corona Virus Disease 2019 (Covid-19) di Kabupaten Sidoarjo, perlu segera diambil langkah-langkah untuk menekan dan memutus mata rantai penyebaran.

2. Bahwa dalam rangka percepatan penanganan penyebaran Corona Virus Disease 2019 (Covid-19) yang semakin meluas di wilayah Jawa Timur, telah ditetapkan Keputusan Menteri Kesehatan Nomor: HK.01.07/MENKES/264/2020 Tentang Penetapan Pembatasan Sosial Berskala Besar di Wilayah Kota Surabaya, Kabupaten Sidoarjo, dan Kabupaten Gresik, Provinsi Jawa Timur Dalam Rangka Percepatan Penanganan Corona Virus Disease (Covid-19).

3. Bahwa berdasarkan pertimbangan sebagaimana dimaksud nomer1 dan 2, perlu menetapkan Peraturan Bupati tentang PedomanPelaksanaan 
Pembatasan Sosial Berskala Besar dalam Penanganan Wabah Corona Virus Disease 2019 di Kabupaten Sidoarjo. Pembatasan sosial yang ditetapkan berdampak pada tutupnya lapak - lapak mereka karena tidak mampu beradaptasi dengan keadaan dan kehabisan modal usaha.Untuk itulah pemerintah berusaha membangkitkan perekonomian para pedagang dengan memberikan modal usaha kepada mereka. Dengan demikian, mereka bisa melanjutkan perjuangan dan kembali membuka usaha dengan modal yang diberikan.

\section{SIMPULAN}

Berdasarkan hasil penelitian yang dipaparkan diatas, skripsi ini membahas mengenai Analisis Dampak Situasi Pandemi Covid-19 terhadap Kesejahteraan Pedagang Pasar Tradisional Larangan di Sidoarjo. Dari permasalahan diatas dapat ditarik kesimpulan sebagai berikut :

1. Pandemi covid-19 sangat berpengaruh terhadap pendapatan pedagang pasar, pendapatan pedagang menjadi menurun. Penurunan pendapatan ini juga sangat berpengaruh pada kelangsungan hidup pedagang. Pedagang yang kehabisan modal tidak dapat melanjutkan usahanya dan akhirnya bisa gulung tikar. Pendapatan merupakan sumber penghasilan seseorang untuk memenuhi kebutuhan sehari - hari dan sangat penting artinya bagi kelangsungan hidup dan penghidupan seseorang secara langsung maupun tidak langsung (Suroto, 2014).

2. Tingkat pendidikan mempunyai pengaruh besar bagi para pedagang pasar dalam memajukan usahanya selama wabah pandemi covid-19. Pedagang yang rata - rata tingkat pendidikannya lebih tinggi, lebih banyak mempunyai inisiatif atau ide - ide yang dapat mendukung kemajuan usaha para pedagang. Pendidikan adalah usaha menyiapkan dan membekali generasi muda ilmu pengetahuan, pengalaman dan kemampuan dalam memecahkan masalah yang prosesnya berlangsung sejak lahir hingga akhir hayat, baik jasmani maupun rohani (Trahati, 2015).

3. Dalam penerapan social distancing, seseorang tidak diperkenankan untuk berjabat tangan serta senantiasa memperhatikan dan menjaga jarak setidaknya 1- 2 meter saat berinteraksi dengan orang lain, terutama dengan seseorang yang sedang sakit atau beresiko tinggi menderita Covid-19, serta tidak meninggalkan rumah kecuali untuk kondisi yang sangat genting (Setiawan, 2020). Semenjak diterapkannya pembatasan sosial (social distancing) penghasilan Pedagang Pasar Tradisional Larangan Sidoarjo mengalami penurunan. Hal ini disebabkan karena para pembeli takut untuk berbelanja ke pasar dan berkerumun. Karena sepinya pembeli membuat pedagang banyak mengalami kerugian.

4. Sehubungan dengan semakin meluasnya penyebaran Corona Virus Disease 2019 (Covid-19) di Kabupaten Sidoarjo, perlu segera diambil langkahlangkah untuk menekan dan memutus mata rantai penyebaran. Pemerintah menetapkan sistem "Pelaksanaan Pembatasan Sosial Berskala Besar (PSBB) (Peraturan Bupati Sidoarjo Nomor 31 Tahun 2020). Langkah - langkah yang ditetapkan tersebut tentunya berdampak pada tutupnya lapak - lapak para pedagang. Tidak jarang diantara mereka ada yang harus gulung tikar selama pandemi karena tidak mampu beradaptasi dengan keadaan dan kehabisan 
modal usaha. Untuk itulah pemerintah berusaha membangkitkan perekonomian para pedagang dengan memberikan modal usaha kepada mereka. Dengan demikian, mereka bisa melanjutkan perjuangan dan kembali membuka usaha dengan modal yang diberikan.

Pandemi covid-19 sangat berpengaruh terhadap pendapatan pedagang pasar, pendapatan pedagang menjadi menurun, banyak dagangan yang belum habis terjual. Saran pada situasi pandemi covid-19 para pedagang harus mempunyai inisiatif untuk mengelola dagangan yang belum habis terjual. Agar pendapatan bisa lebih banyak, selain sisa dagangan yang sudah diolah dapat dijual dirumah, dan dagangan bisa dijual secara online (penjualan secara online memastikan penjual dan pembeli tidak saling bertemu, meminimalisir terjangkitnya covid-19). Misalnya pedagang sayur bisa mengolah sayuran menjadi lumpia basah atau lumpia kering, pedagang ayam bisa mengolah ayam tersebut menjadi ayam geprek, pedagang pisang bisa mengolah pisang menjadi pisang keju atau penjual buah yang lain bisa mengolah buah itu menjadi jus buah atau salad buah, pedagang sosis bisa mengolah sosis menjadi sosis goreng atau sosis bakar, pedagang sepatu dan sandal bisa menjual dagangannya dengan murah (memberi diskon), pedagang alat elektronik bisa membuka jasa servis dirumah. Dengan adanya peraturan pembatasan sosial (social distancing) sangat berpengaruh terhadap pendapatan pedagang pasar, pendapatan pedagang pasar menurun. Saran pembatasan sosial menyebabkan para pembeli menjadi takut untuk datang untuk membeli dagangan, seharusnya pedagang lebih berinisiatif untuk mengurangi dagangan agar tidak banyak merugi. Dimasa pandemi covid19 pemerintah menganjurkan para pedagang untuk tetap menjaga kesehatan dengan mematuhi protokol kesehatan, selain itu pemerintah juga memberi bantuan modal usaha (tidak merata). Saran protokol kesehatan memang harus tetap dilakukan para pedagang pasar agar dapat terhindar dari covid-19, dan untuk pemerintah supaya dapat lebih meratakan bantuan modal usaha yang diberikan kepada para pedagang (menghindari kecemburuan sosial antar pedagang). Bantuan dari pemerintah yang tidak merata tidak menjamin kesejahteraan secara utuh, setidaknya bantuan harus diberikan secara berkala dan merata.

\section{DAFTAR PUSTAKA}

Abdusshomad, A. (2020). Pengaruh Covid-19 terhadap Penerapan Pendidikan Karakter dan Pendidikan Islam. QALAMUNA: Jurnal Pendidikan, Sosial, dan Agama, 12(2), 107-115.

Hadiwardoyo, W. 2020. Kerugian Ekonomi Nasional Akibat Pandemi Covid-19. Jakarta: Journal of Business \& Entrepreneurship, 2(2), 83-92.

Hanoatubun, S. 2020. Dampak Covid-19 terhadap Prekonomian Indonesia. Salatiga: Journal of Education, Psychology and Counseling, 2(1), 146-153.

Masitoh, Eis Al. 2013. Upaya Menjaga Eksistensi Pasar Tradisional : Studi Revitalisasi Pasar Piyungan Bantul. Jurnal. Jurusan Pengembangan Masyarakat Islam, Fakultas Dakwah, UIN Sunan Kalijaga. 
Bharanomics

Vol. 2 No. 12021

Ilham Putra Sahbana dkk., Analisis Dampak Situasi Covid-19

Nordhaus., dan Samuelson. 2013. Ilmu Mikro Ekonomi. Jakarta: Global Media Edukasi.

Pratama, D. S., Iwang, G., dan Ine, M. 2012. Analisis Pendapatan Nelayan Tradisional Pancing Ulur di Kecamatan Manggar, Kabupaten Belitung Timur. Bangka Belitung: Fakultas Perikanan dan Ilmu Kelautan Universitas Padjadjaran.

Setiawan, Y. I. S. (2020). Penetapan Karantina Wilayah Menurut Pandangan Legal Positivisme Dalam Rangka Pencegahan dan Pemberantasan Pandemi Coronavirus Disease (Covid)-19.

Sodikin., dan Riyono. 2014. Akuntansi Pengantar I. Yogyakarta: Sekolah Tinggi Ilmu Manajemen YKPN.

Suroto. 2014. Strategi pembangunan dan Perencanaan Perencanaan Kesempatan Kerja.Yogyakarta: Universitas Gajah Mada.

Trahati, Melia Rimadhani. 2015. Implementasi Pendidikan Karakter Peduli Lingkungan di Sekolah Dasar Negeri Tritih Wetan 05 Jeruklegi Cilacap. Yogyakarta: Jurnal Pendidikan Guru Sekolah Dasar Edisi 12 Tahun ke IV Agustus 2015 Universitas Negeri Yogyakarta.

Yunus, N. R., dan Rezki, A. 2020. Kebijakan Pemberlakuan Lock Down Sebagai Antisipasi Penyebaran Corona Virus Covid-19. Jakarta: Jurnal Sosial dan Budaya Syar-i, 7(3), 227-238. 